\title{
Formation and disposal of wastes and determination of wastefulness indicators in sugar industry
}

\author{
Maria Strzelczyk, Aleksandra Steinhoff-Wrześniewska \\ Institute of Technology and Life Sciences, al. Hrabska 3, Falenty 05-3089 Raszyn, Poland, e-mail: mst@dob-imuz.pl, \\ aleksandra.sw@gmail.com
}

\begin{abstract}
The studies covered sugar industry. The analyses of wastes and wastefulness indicators in the sugar industry were performed in the paper. The results showed that processing of sugar beet generates the formation of huge quantities of side products and wastes. The values of indicators obtained in individual factories were very similar.
\end{abstract}

Keywords: wastes, wastefulness indicators, sugar industry.

\section{INTRODUCTION}

Processing of farm and food raw materials is linked with the formation of several kinds of wastes. The raw and other materials are not fully (in 100\%) utilized, resulting in the formation of remains in the form of raw and other material remnants. The production process is therefore accompanied by the formation of a whole series of side products, technological wastes as well as operational wastes, resulting from the functioning of factories. The major types of food processing industries associated with environmental objectives may be regarded as: the agricultural industry, the meat and fish industry, fruit and vegetable industry, the dairy and the packing industries. Each step in food industry system is characterized by the byproducts, waste and air emissions with a possible impact on the environment ${ }^{1}$.

Formation of certain wastes, and especially their large quantity, is not always unavoidable and justified. The practice so far and the operations already applied in many factories aimed at limiting the formation of wastes, have shown that in this scope there are large possibilities of achieving positive effects.

Legal regulations in the field of wastes, both of the European Union and also of Poland, impose on all plants performing operations causing formation of wastes, the obligation of preventing such formation and minimization of their quantity. In accordance with the Polish act on wastes ${ }^{2}$, "anyone who undertakes activity causing or liable to cause the formation of wastes should plan, design and conduct such activity in such a way so as to:

- prevent the formation of wastes or limit the amount of wastes and their negative reaction on the environment while generating products, during and after the completion of their utilization;

- ensure, in accordance with the principles of environmental protection, recycling if their formation was unpreventable;

- ensure, in accordance with the principles of environmental protection, rendering harmless the wastes whose formation was unpreventable or unrecyclable."

Fulfillment of these requirements depends among others on technical, technological and economical conditions as well as the ecological awareness of the entrepreneurs and workers, and first all on the rational performance of waste disposal, material management in factories and on operations aimed at the minimization of wastes and their proper disposal.

The purpose of the paper was to determine the wastefulness indicators in the sugar industry and to make the assessment of waste disposal in the selected factories of this branch.

\section{RESEARCH PART}

The material constituted opinion polls conducted in 8 sugar factories covering the data, concerning the amount of the production, the quantity of the raw material processed and the quantity of the wastes generated in the factory, the method of their disposal as well as the undertaken and planned operations aimed at minimizing their occurrence. Subjected to analysis were the wastes characteristic of this branch of food processing. The data collected covered the $2-4$ years of the production period (2005 - 2008).

To define the wastefulness indicators adopted the quantity,defining the amount of waste for every ratio between the unit of product or raw material. Because there is one main product (sugar) produced in sugar industry, that is why in this paper the wastefulness indicator was calculated as the ratio between the unit of waste on the unit of the product. The data come from surveys conducted in sugar factories in Poland.

The amount of the raw material processed in the individual factories varied from 228644 to $570896 \mathrm{Mg} /$ year and the amount of sugar produced from 39489 to 81176 $\mathrm{Mg} /$ year.

\section{DISCUSSION OF THE RESULTS}

The sugar branch is characterized by an exceptionally high indicator of the formation of wastes and side products arising during the production process (about $75 \%$ of all food industry wastes) ${ }^{3}$. In the year 2008, the quantity of the wastes formed in the subsection DA amounted to 6733.4 thousand $\mathrm{Mg}$, of which almost $43 \%$ constituted the wastes from the sugar industry ${ }^{4}$. Molasses, sediment from washing and preparing the raw material, liming and waste plant mass are formed in the largest quantities. Depending on the carriers utilized in the sugar industry, significant quantities of wastes from the production of heat energy, which are mainly ashes and slag, are also arising. 
Table 1. Average amount of production, quantity of raw material processed as well as basic post-production remains in the factories studied

\begin{tabular}{|c|c|c|c|c|c|c|c|c|}
\hline \multirow[b]{2}{*}{$\begin{array}{l}\text { Factory } \\
\text { symbol }\end{array}$} & \multirow[b]{2}{*}{$\begin{array}{l}\text { Num- } \\
\text { ber of } \\
\text { years }\end{array}$} & \multirow[b]{2}{*}{$\begin{array}{c}\text { Quantity of } \\
\text { raw material } \\
{[\mathrm{Mg}]}\end{array}$} & \multirow[b]{2}{*}{$\begin{array}{c}\text { Amount of } \\
\text { production } \\
\text { [Mg] }\end{array}$} & \multicolumn{5}{|c|}{ Remains } \\
\hline & & & & $\begin{array}{l}\text { Pulp } \\
\text { [Mg] }\end{array}$ & $\begin{array}{c}\text { Molasses } \\
{[\mathrm{Mg}]}\end{array}$ & $\begin{array}{c}\text { Waste plant } \\
\text { mass } \\
{[\mathrm{Mg}]}\end{array}$ & $\begin{array}{c}\text { Sediment from } \\
\text { washing and } \\
\text { cleaning of beet } \\
{[\mathrm{Mg}]}\end{array}$ & $\begin{array}{c}\text { Defecation } \\
\text { lime } \\
\text { [Mg] }\end{array}$ \\
\hline $\mathrm{F} 1$ & 4 & 343724 & 52454 & 182404 & 12841 & 6531 & 40349 & 26243 \\
\hline $\mathrm{F} 2$ & 4 & 475783 & 70487 & 235027 & 17113 & ${ }^{*}$ & 30851 & 17175 \\
\hline F3 & 4 & 522637 & 77146 & 207241 & $*$ & 2869 & 37275 & 25852 \\
\hline F4 & 4 & 403140 & 61024 & 213834 & 13384 & * & 14477 & 18978 \\
\hline F5 & 3 & 345718 & 52166 & 182747 & 12780 & 3864 & 16333 & 17792 \\
\hline F6 & 4 & 380222 & 55642 & * & 14027 & 6562 & 42029 & 23717 \\
\hline $\mathrm{F} 7$ & 2 & 510964 & 75669 & 264616 & ${ }^{*}$ & 3741 & ${ }^{*}$ & 25804 \\
\hline F8 & 3 & 393530 & 59975 & 209429 & 12403 & 7508 & 26943 & 21779 \\
\hline
\end{tabular}

* - no data

Table 2. Indicators of formation of selected wastes in $\mathrm{Mg}$ per $1 \mathrm{Mg}$ of sugar produced

\begin{tabular}{|c|c|c|c|c|c|c|}
\hline \multirow{2}{*}{ Factory symbol } & \multirow{2}{*}{ Amount of production } & \multicolumn{5}{|c|}{ Quantity of post-production remains $[\mathrm{Mg} / \mathrm{Mg}]$} \\
\hline & & pulp & molasses & wpm & sediment & lime \\
\hline F1 & 52454 & 3.5 & 0.24 & 0.12 & 0.77 & 0.50 \\
\hline F2 & 70487 & 3.3 & 0.24 & 0.09 & 0.44 & 0.24 \\
\hline F3 & 77146 & 2.7 & * & 0.04 & 0.48 & 0.34 \\
\hline $\mathrm{F} 4$ & 61024 & 3.5 & 0.22 & * & 0.24 & 0.31 \\
\hline F5 & 52166 & 3.5 & 0.24 & 0.07 & 0.31 & 0.34 \\
\hline F6 & 55642 & ${ }^{*}$ & 0.25 & 0.12 & 0.76 & 0.43 \\
\hline F7 & 75669 & 3.5 & * & 0.05 & $*$ & 0.34 \\
\hline $\mathrm{F} 8$ & 59975 & 3.5 & 0.21 & 0.13 & 0.45 & 0.36 \\
\hline Average & 63070 & 3.0 & 0.22 & 0.09 & 0.47 & 0.35 \\
\hline
\end{tabular}

* no data

wpm- waste plant mass

sediment- sediments from washing and cleaning of beet

lime- defecation lime

In foreign literature, both the consumption of materials as well as the quantities of the wastes formed in the production process are referenced to the amount of the production. As is concluded from Table 2, for every ton of sugar produced, there is on average $4.1 \mathrm{Mg}$ of the wastes directly connected with processing of raw material. In addition, depending on the applied source of heat energy (mainly on the evaporating station), considerable quantities of ashes and slag averaging $0.06 \mathrm{Mg}$ per $1 \mathrm{Mg}$ of sugar produced are formed in most factories.

In the factories studied, the quantity indicators of the wastes converted into the quantity of the processed raw material amounted to:

- pulp (020480) 37.5 - 53.2, average $48.5 \%$

- molasses (020499) 3.2 - 3.7, average 3.5\%

- waste plant mass (020103) 0.2 - 1.9, average $1 \%$

- sediment from washing and cleaning (020401) 3.1 -

11.7, average $6.8 \%$

- liming (020402) 3.6 - 7.6, average 5.3\%

- ashes and slag (100180) $0.7-1.6 \%$ in case of using solid fuels.

Operational wastes such as the ones below are formed in lesser quantities in sugar factories:

- sorbents, filtration materials $(150203,150202) 0.05$

- $9 \mathrm{Mg} /$ year

- burnt out fluorescent lamps containing mercury (160213) $0.01-0.29 \mathrm{Mg} /$ year

- chemicals (160506) $0.001-0.3 \mathrm{Mg} /$ year

- packaging containing dangerous substances (150110)

$0.05-0.77 \mathrm{Mg} /$ year
- waste lubrication, engine and transmission oils (130208) 0.2 - $4.3 \mathrm{Mg} /$ year.

The inseparable problem of production is the formation of the packaging wastes:

- paper and cardboard packaging (150101) 5 - $87 \mathrm{Mg} /$ year

- plastics packaging (150102) 0.3 - $26.6 \mathrm{Mg} / \mathrm{year}$

- wooden packaging (150103) 9 - $58 \mathrm{Mg} / \mathrm{year}$.

The wastes resulting from the functioning of the factory and utilization of the structures and the equipment, which to a large extent depends on the technical state and capital constructions conducted:

- communal wastes (200301) 35.4 - $105.8 \mathrm{Mg} /$ year

- scrap (170405) 16.33 - $911 \mathrm{Mg} /$ year

- rubble (170107, 170101) 0.5 - $1251 \mathrm{Mg} /$ year.

The structure of the remains formed in the sugar industry is presented in Fig.1. Over 80\% constitutes organic remains. The pulp, remains after the extraction-diffusion of sugar from beet slices; in the factories under study it constituted on average $74 \%$ of all the solid remains formed in the sugar factory. The beet pulp, if meeting relevant quality requirements, should be treated as the side product useful for various purposes. First of all:

- as feed for animals (particularly for cattle),

- as raw material for further processing (production of food pectins, pectin glue, dietetic cellulose and lactic acid).

The high dampness of beet pulp causes its low durability. To enable the storage of the pulp over a longer period, it should be subjected to durability processes (drying, souring). 


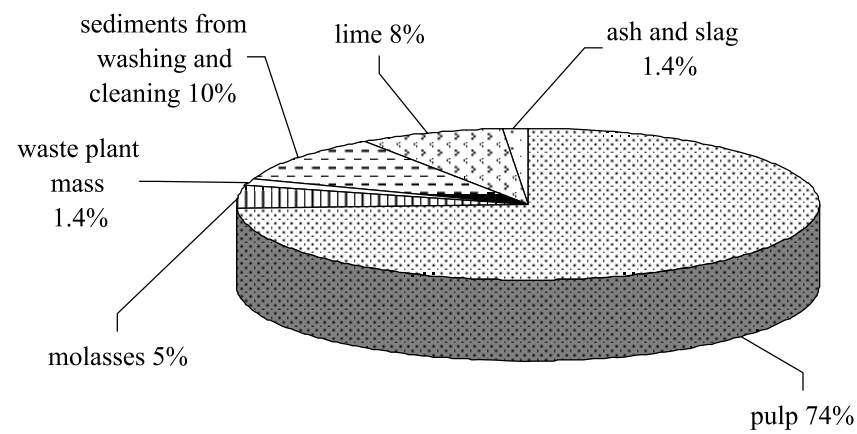

Figure 1. Structure of other solids arising in the sugar industry

In exceptional cases, when there is no possibility of selling the pulp, it is recommended to subject it to composting, together with other organic wastes while maintaining appropriate proportions of the components (particularly C:N within about 25:1 and C:P about 100:1) and chemical reaction approaching neutral. The compost obtained is the valuable and safe organic fertilizer which can be used in agriculture and horticulture (instead of peat).

Beet pulp can also be used for the production of methane in the anaerobic fermentation process. The beet pulp contains large quantities of carbohydrates which increase the quantity of methane educed in wastewater fermentation chambers (digesters). Utilization of the pulp for the production of methane is widely applied in west European countries.

Molasses, the post-crystallization run-off syrup, has the form of syrup-like liquid of dark, brown colour. It constitutes about $5 \%$ of the post-production remains. It is a side product containing significant quantities of carbohydrates and forms the raw material for the fermentation industry (yeast products, production of ethanol in distilleries). In the case of the lack of the possibility of sale, it is a difficult waste for disposal, both because of economical as well as ecological reasons. It may be used as an additive to feed for animals and for the fertilization of soil (in the limited scope).

Molasses can also be utilized in building industry as an additive to concrete, improving its strength, performing the function of plasticizers.

At present, the utilization of molasses for the production of ethanol as a renewable source of energy (additive to fuels) should be the most justified and recommended.

Waste plant mass arises during various mechanical operations, reloading and hydro-transportation and constitutes about $2 \%$ of all wastes. In the factories under study, the average annual quantity of these wastes exceeds 5 thousand Mg. They are mainly tails, beet pieces, straw and other plant pollutants. Possible directions of disposal being sugar recovery, are adding to pulp and assigning for feed purposes. Unfortunately, both these directions require cleaning and reduction in the size of these wastes, which is linked with the necessity of incurring costs. The simplest way of utilizing them, therefore is composting or using as additive for the production of biogas.

Sediments after washing and cleaning the raw material constitute about $10 \%$ of wastes in the factories under study. They originate from hydro-transportation and washing of the beet, their quantity depending on the contamination with soil. This waste should be utilized in agriculture (spreading on soil) and for re-cultivation purposes and filling of excavations. Due to its composition (fertile soil and organic substance) as well as base reaction, it is useful for such purposes. The sandy fraction can be used in construction work as the aggregate.

Defecation-saturation lime formed as a result of cleaning diffusion juice, because of its chemical composition, is a valuable fertilizer containing $30-40 \%$ lime and lesser quantities of other mineral components. Its percentage share amounts to about $8 \%$ of all the wastes arising in sugar factories. The nitrogen content in it is similar to that in manure (about $0.5 \%$ ). Defecation-saturation lime should be distributed among farmers as lime fertilizer utilized to improve the reaction (neutralization) of acidic soil. It is also possible to utilize this waste as a micro-additive in the coking process. Also practiced is the utilization of defecation-saturation lime as an additive to feed and also for the production of building binders (mortars) because it contains $66-80 \%$ of $\mathrm{CaCO}_{3}$ as converted into dry mass ${ }^{5}$.

The basic fuel used in drying rooms and boiler rooms is hard/bituminous coal, whereas coke is used in lime kilns. Utilization of solid fuels is accompanied by the formation of wastes in the form of ashes and slag. Ashes and slag constitute by weight about $1.5 \%$ of all the solid wastes arising in sugar factories. The basic method of their disposal is using them for hardening of access roads and squares, for building material (production of cement, binders, concrete mixes) and also utilization in the construction of roads.

In food industry plants, beside the wastes resulting from the processing of basic raw material, wastes are formed connected with the utilization of additives or auxiliary materials, wastes resulting from the utilization of the equipment and buildings as well as communal wastes. They include the packaging and remains of disinfectants, sorbents, filtration materials, burnt out fluorescent lamps containing mercury, chemicals, the packaging containing dangerous substances, spent lubrication, engine and transmission oils, rubble, scrap and communal wastes. Their total quantity does not exceed $1 \%$ of solid wastes.

These wastes should be collected selectively and transferred to specialized firms to be subjected to recycling or utilization. It is forbidden to mix wastes of different categories.

The methods presented in this paper for the disposal of wastes and side products arising in the sugar industry: pulp, molasses, waste plant mass, flume mud and defecation-saturation lime are widely discussed in available literature $^{3,6-8}$. In order to achieve the best effects to decrease the influence of industry on the environment, it is advisable to introduce environment management systems, which means constant control and monitoring of the parameters achieved and also constant endeavour to improve them through proper in-plant and store management, to improve the efficiency of the production processes and training of workers.

Most of the factories surveyed indicated the possibility of reducing the quantity of wastes arising through the modernization of the technological solutions applied (heating systems, transportation lines and preparation of raw material, evaporation stations, furnaces) as well as methods of disposal and neutralization of the post-production 
remains for power engineering purposes. The basic problem is the necessity of incurring high costs of modernizing the enterprise to decrease the influence of its functioning on the environment.

The operations recommended by the sugar factories under study in connection with improvement of waste management:

- limiting the quantity of packaging wastes: construction of sugar silos and transportation of sugar to industrial customers by tank trucks, utilization of big-bag packaging,

- reducing the quantity of organic wastes - collection of beet preliminary cleaned on the planter's field, modernization of the cleaning station to separate the organic part in the form of beet tails, installation of the system for dewatering the beet pulp, installation of the system utilizing waste organic mass for the production of biogas,

- reducing the quantity of defecation-saturation lime: dewatering of lime on high-capacity presses and obtaining the precipitate of dry substance content up to $75 \%$,

- modernization of heat management: installation of the boilers of high efficiency, optimization of the operation of vapour receivers from evaporators, purchase of fuel of higher heating value, replacement of continuous diffusers with column-type, modernization of central heating of office and personnel utility premises,

- reducing energy consumption for the production: utilizing continuous systems of massecuite boiling and efficient centrifuges with power recovery, decreasing the consumption of limestone and coke - optimizing the operation of cleaning station,

- modernization of filtration station: decreasing the consumption of chemical agents.

\section{CONCLUSIONS}

- The studies carried out showed that processing of sugar beet generates the formation of huge quantities of side products and wastes e.g. there is on average $4.1 \mathrm{Mg}$ of wastes directly connected with the processing of raw material.

- The values of indicators obtained in individual factories were very similar.

- Data analysis showed proper waste disposal/management in the enterprises surveyed.

- Possibilities were indicated for the reduction of the quantity of wastes through the introduction of organizational and technological changes.

The opinion poll studies and surveys were conducted to the order of the Ministry of Agriculture and Rural Development.

\section{LITERATURE CITED}

1. Kroyer, G. Th. (1995). Impact of food processing on the environment - an overview. Lebensm. Wiss. U.-Technol., $28,547-552$.

2. Journal of Laws. No. 62, poz. 628, (2001).( Ustawa z dnia 27 kwietnia 2001 o odpadach).

3. Environment protection in sugar industry. Collective work. (1998). (Praca zbiorowa, Ochrona środowiska w przemyśle cukrowniczym, Wyd. FAPA.

4. Environment. (2009).(Ochrona Środowiska. GUS).
5. Waste management guide. Editor Krzysztof Skalmowski (2009). Warsaw. (Poradnik gospodarowania odpadami. Pod red. Krzysztofa Skalmowskiego Tom II.).

6. Outlines for the Best Available Technique. Sugar production. Ministry of Environment. 2004. (BATNEEC Wytyczne najlepszej dostępnej techniki. Produkcja Cukru, Ministerstwo Srodowiska).

7. Kumider, J. (1996).The agri-food processing of waste utylization. (Utylizacja odpadów przemysłu rolnospożywczego. Wyd. Akademii Ekonomicznej w Poznaniu).

8. Kumider, J. \& Zielnica, J. Bioenergetics a chance for environment. (2006)(Bioenergetyka szansą dla środowiska naturalnego, AE Poznań). Warsaw. 